\title{
Hydrophilic Extractives in Heartwood of European Larch (Larix decidua Mill.)
}

\section{Hidrofilni ekstraktivi u srži europskog ariša (Larix decidua Mill.)}

\author{
Original scientific paper • Izvorni znanstveni rad \\ Received-prispjelo: 17. 3. 2016. \\ Accepted-prihvaćeno: 6. 9. 2016. \\ UDK: $630 * 811.52 ; 630 * 866 ; 674.032 .475 .34$ \\ doi:10.5552/drind.2016.1618
}

\begin{abstract}
The heartwood of two European larch trees was examined for the content of hydrophilic extractives. Ethanol was used as a solvent for extractions of adequately pretreated samples, while gas chromatography with flame ionisation detection (GC-FID), gas chromatography coupled to mass spectrometry (GC-MS) and high performance size exclusion chromatography (HPLC-SEC) were applied for analyses. Different phenolic compounds, such as flavonoids and lignans were identified and quantitatively evaluated. The most abundant flavonoids were taxifolin and dihydrokaempferol, while the main lignan was secoisolariciresinol. Contents of flavonoids and lignans, measured at different stem heights, varied between 10.6 and $15.7 \mathrm{mg} / \mathrm{g}$. At lower and medium heights flavonoids prevailed, while at upper stem positions the concentrations of lignans significantly increased. In addition, some trimeric and tetrameric phenolic structures were also detected. There was very little variation in the composition of hydrophilics between the two examined trees. The identified flavonoids and lignans are classified as very strong antioxidants.
\end{abstract}

Key words: European larch, heartwood, hydophilic extractives, flavonoids, lignans, chromatographic techniques

SAŽETAK • U radu su prikazani rezultati istraživanja hidrofilnih ekstraktivnih tvari u srži dvaju stabala europskog ariša. Kao otapalo za ekstrakciju prethodno adekvatno obrađenih uzoraka upotrijebljen je etanol, a za kemijske analize primijenjene su plinska kromatografija s plameno-ionizacijskim detektorom (GC-FID), plinska kromatografija povezana s masenom spektrometrijom (GC-MS) i tekućinska kromatografija visoke djelotvornosti (HPLC-SEC). U uzorcima su identificirani i kvantitativno procijenjeni različiti fenolni spojevi kao što su flavonoidi i lignani. Taksifolin i dihidrokamferol najzastupljeniji su flavonoidi, a glavni je lignan sekoizolaricirezinol. Cjelokupne koncentracije flavonoida i lignana koje su određivane u srži na različitim visinama stabla variraju između 10,6 i 15,7 mg/g. Na niskim i srednjim visinama prevladavaju flavonoidi, a na visinama bližima vrhu stabla zabilježen je značajan porast koncentracije lignana. Također, u ekstraktima su identificirani trimerni i tetramerni fenolni spojevi. Varijacije u sastavu hidrofilnih ekstraktiva između oba stabla bile su vrlo malene. Identificirani flavonoidi i lignani poznati su kao vrlo jaki antioksidansi.

Ključne riječi: europski ariš, srž, hidrofilni ekstraktivi, flavonoidi, lignani, kromatografske tehnike

\footnotetext{
${ }^{1}$ Author is researcher at the Pulp and Paper Institute, Ljubljana, Slovenia. ${ }^{2}$ Authors are professors at the University of Ljubljana, Biotechnical Faculty, Ljubljana, Slovenia.

Autorica je znanstvenica Instituta za celulozu i papir, Ljubljana, Slovenija. ${ }^{2}$ Autorice su profesorice Sveučilišta u Ljubljani, Biotehnički fakultet, Ljubljana, Slovenija.
} 


\section{INTRODUCTION}

\section{UVOD}

Hydrophilic extractives are nonstructural wood components, which are readily soluble in polar solvents, such as acetone, methanol, ethanol and water. In contrast to lipophilic compounds in resin canals and parenchyma cells of sapwood (Zule et al., 2015), they mainly originate from the transition zone between heartwood and sapwood. Their concentrations are the highest at the boundary, after which they gradually decrease in radial direction towards the pith. Hydrophilics are mostly composed of phenolic compounds. Their synthesis is genetically regulated so each tree species contains specific compounds by which it differs from other species. Phenolic type compounds are comprised of aromatic components from simple phenols to complex phenolic polymers.

The most important are compounds with two phenolic groups, e.g. stilbenes, flavonoids and lignans (Hillis, 1962; Shen et al., 1986; Kolhir et al., 1996; Debell et al., 1997; Celimene et al., 1999; Eaton and Hale, 1999; Kleist and Schmitt, 1999; Stenius, 2000, Willför et al., 2004). Flavonoids have a characteristic diphenylpropane $\left(\mathrm{C}_{6} \mathrm{C}_{3} \mathrm{C}_{6}\right)$ carbon skeleton. Both aromatic rings in the molecule usually contain hydroxyl groups. The most abundant flavonoids in wood are dihydrokaempferol $\left(\mathrm{C}_{15} \mathrm{H}_{12} \mathrm{O}_{6}, \mathrm{M}_{\mathrm{w}}=288\right)$, taxifolin $\left(\mathrm{C}_{15} \mathrm{H}_{12} \mathrm{O}_{7}, \mathrm{M}_{\mathrm{w}}=304\right)$, naringenin $\left(\mathrm{C}_{15} \mathrm{H}_{12} \mathrm{O}_{5}, \mathrm{M}_{\mathrm{w}}=272\right)$ and catechin $\left(\mathrm{C}_{15} \mathrm{H}_{14} \mathrm{O}_{6}\right.$, $\left.M_{w}=290\right)$ (Hillis, 1962; Sjöstrom, 1981; Stenius, 2000). In addition to simple flavonoids, there are also flavonoid polymers with 3 to 8 flavonoid units, which are known as condensed tannins.

Lignans are an important group of plant phenols and are widespread in the plant world. Typical for them is oxidative coupling of two phenylpropane $\left(\mathrm{C}_{6} \mathrm{C}_{3}\right)$ units via linkage between $\beta$-positions on propane side chains. In addition to dimeric lignans, minor quantities of trimers (sesquilignans) and tetramers (dilignans) can also be found in wood. They are generally called oligolignans. Several tens of lignans have been identified so far in wood tissues. However, the predominating are dimeric components, e.g. hydroxyimatairesinol $\left(\mathrm{C}_{20} \mathrm{H}_{22} \mathrm{O}_{7}, \mathrm{M}_{\mathrm{w}}=374\right)$, pinoresinol $\left(\mathrm{C}_{20} \mathrm{H}_{22} \mathrm{O}_{6}, \mathrm{M}_{\mathrm{w}}=358\right)$, lariciresinol $\left(\mathrm{C}_{20} \mathrm{H}_{24} \mathrm{O}_{6}, \mathrm{M}_{\mathrm{w}}=360\right)$, secoisolariciresinol $\left(\mathrm{C}_{20} \mathrm{H}_{26} \mathrm{O}_{6}, \mathrm{M}_{\mathrm{w}}=362\right)$ and nortrachelogenin $\left(\mathrm{C}_{20} \mathrm{H}_{22} \mathrm{O}_{7}\right.$, $\left.\mathrm{M}_{\mathrm{w}}=374\right)$, Lignans appear as free components or linked to carbohydrates via glycoside bonds (Ward, 1997; Bohm, 1998; Stenius, 2000; Willför et al., 2006).

On account of their specific chemical structure and related antioxidative properties, phenolic compounds are toxic for numerous microorganisms, fungi and insects. They function as powerful natural biocides and enable chemical protection of wood against harmful impacts and biological degradation (Rennerfelt and Nacht, 1955; Hart, 1989; Willför, 2002).

Wood of larch (various species of the genus Larix) is generally known as durable as well as resistant against weather conditions, acids and water. So far, several authors have studied chemical composition of hydrophilic extractive fraction of the heartwood of dif- ferent larch species (Gripenberg, 1952; Brewerton, 1956; Nair and von Rudloff, 1960; Gardner and Barton, 1960; Sasaya et al., 1970; Lepteva et al., 1971; Tyukavkina et al., 1973; Giwa and Swan, 1975; Keith and Chauret, 1988; Chui and Mackinnon-Peters, 1995). They found out that the predominating hydrophilics were flavonoids. Their concentrations, measured in radial direction at representative stem height $(1.5 \mathrm{~m})$, were highest at the heartwood/sapwood boundary.

Some researchers studied the correlation between the content of hydrophilics and natural durability of larch heartwood (Doi et al., 1998; Ohmura et al., 1999; Windeisen et al., 2002; Windeisen and Wegener, 2003; Gierlinger et al., 2002, 2003, 2004). Strong connection between extractive structure and rotting resistance has been confirmed.

Recently, many studies have also been dedicated to evaluation of larch wood as potential source of technologically important highly bioactive phenolic compounds, such as taxifolin, dihydrokaempferol and secoisolariciresinol (Babkin et al., 1999; Babkin et al., 2001; Aleksandrova et al., 2002; Ivanova et al., 2012; Ostroukhova et al., 2012; Wen-jie et al., 2005, Willför et al., 2003).

Most authors focused on chemical characterization of larch heartwood at the representative stem height $(1.5 \mathrm{~m})$, while there is almost no data on the content of extractives at different positions along the stem and in branches.

The aim of the present work was to make a detailed chemical characterization of hydrophilics in the heartwood of European larch (Larix decidua Mill.) and to determine their variability in longitudinal direction within a tree and between two trees selected for analyses. This article is the continuation of the previously published work (Zule et al., 2015), where lipophilic extractive compounds of the same samples were characterized.

\section{MATERIALS AND METHODS}

\section{MATERIJALI I METODE}

\subsection{Samples \\ 2.1. Uzorci}

Two larch trees (Larix decidua Mill.) were felled at the end of June, 2009 in the Alpine region of Slovenia at the altitude of $1000 \mathrm{~m}$. They originated from a mixed forest where beech (Fagus sylvatica L.) and spruce (Picea abies Karst.) predominated. Both larch trees were 180 years old and about $30 \mathrm{~m}$ high. They were healthy without visual damage.

About $5 \mathrm{~cm}$ thick discs were cut from the trunks at the base ( $50 \mathrm{~cm}$ above ground) as well as at the heights of 8,18 and $28 \mathrm{~m}$. The discs were debarked and representative sections of heartwood (circular sectors from the pith to the heartwood/sapwood boundary) were cut into smaller pieces, which were subsequently frozen at $-24^{\circ} \mathrm{C}$ prior to analysis.

\subsection{Drying and grinding \\ 2.2. Sušenje i mljevenje}

Frozen samples were first conditioned at room temperature, after which they were cut into short splin- 
ters, freeze-dried for 24 hours (Martin Christ Gefriertrocknungsanlagen $\mathrm{GmbH}$ ) and ground by means of a Wiley laboratory mill $(0.150 \mathrm{~mm})$ to wood meal. The latter was freeze-dryed again for 24 hours in order for volatile compounds to be removed.

\subsection{Extraction}

\subsection{Ekstrakcija}

Extractions were conducted by means of an accelerated solvent extraction system (ASE) using the instrument Dionex ASE 200. About $5 \mathrm{~g}$ of each freezedried powdered sample was weighed into a metal extraction cell and sequentially extracted first with hexane $(\mathrm{V}-50 \mathrm{ml})$ to remove lipophilic fraction (Zule et al., 2015) and afterwards with $95 \%$ ethanol (V-50 ml) to isolate hydrophilic extractive portion. The temperature of the first extraction step was $90{ }^{\circ} \mathrm{C}$, pressure 13.8 $\mathrm{MPa}$ and extraction time 10 minutes (2 static cycles with static time of 5 minutes). Ethanol extraction was carried out at $100{ }^{\circ} \mathrm{C}$ under the same experimental conditions. Both extractions were performed under the stream of nitrogen.

\subsection{Derivatization of extractives}

2.4. Derivatizacija ekstraktiva

All ethanol extracts were derivatized prior to chromatographic analyses (GC-FID, GC-MS) by which components with hydroxyl groups, such as flavonoids and lignans, were converted to the corresponding trimethylsilyl (TMS) derivatives, which where less polar and so more convenient for subsequent chromatographic analyses. $2 \mathrm{ml}$ of internal standard solution were added to each extract, containing about $0.5 \mathrm{mg}$ of extractive compounds. Internal standards were heneicosanoic acid (S1), betulinol (S2), cholesteryl heptadecanoate (S3) and 1.3-dipalmitoyl-2-oleyl glycerol (S4), all having concentration of $0.02 \mathrm{mg} / \mathrm{ml}$. The mixture of a sample and standards was dried under the stream of $\mathrm{N}_{2}$ and in vacuum desiccator at $40{ }^{\circ} \mathrm{C}$, after which sylilation reagents were added: $80 \mu \mathrm{l}$ BSTFA (bis-trimethylsilyl-trifluoroacetamide) and $20 \mu \mathrm{l}$ TMCS (trimethyl-chlorosilane) in $20 \mu \mathrm{l}$ of pyridine. The reaction mixture was heated for 1 hour at $70{ }^{\circ} \mathrm{C}$, than it was cooled and injected into gas chromatograph (Willfor, 2007).

\subsection{Chromatographic analyses of extractives}

2.5. Kromatografska analiza ekstraktiva

\subsubsection{Identification of extractive compounds by GC-MS \\ 2.5.1. Identifikacija ekstraktivnih spojeva metodom} GC-MS

Characteristic components of the representative ethanol extracts were identified by means of gas chromatography coupled to mass spectroscopy (GC-MS). The analyses were performed on the HP 6890-5973 GC-MSD instrument. The separation was carried out on the HP-1 (30 m x $0.25 \mathrm{~mm} \times 0.25 \mu \mathrm{m})$ capillary column under the following experimental conditions: temperature program of column heating $80{ }^{\circ} \mathrm{C}, 8{ }^{\circ} \mathrm{C} /$ min, $290{ }^{\circ} \mathrm{C}$; carrier gas $\mathrm{He}(0.9 \mathrm{ml} / \mathrm{min})$; split injector $(1: 15)-260{ }^{\circ} \mathrm{C}$; MS-EI detector (source temp. $280{ }^{\circ} \mathrm{C}$,
$70 \mathrm{eV}$, quadrupole temp. $\left.180{ }^{\circ} \mathrm{C}\right)$. Mass range $(\mathrm{m} / \mathrm{z})$ was between 10 and 1050 . For positive identification of individual compounds, the mass spectra of their chromatographic peaks were compared with spectra of pure compounds from the Wiley Registry NIST 2008 Mass Spectral Library. On both GC-FID and GC-MS chromatograms there was practically the same sequence of chromatographic peaks of individual compounds as similar long capillary columns were used, by which reliability of identification was ensured and quantitative work facilitated (Willfor, 2007).

\subsubsection{GC-FID analysis on long capillary column 2.5.2. GC-FID analiza na dugoj kapilarnoj koloni}

The determination of individual flavonoids, lignans and other hydrophilic compounds was accomplished by means of gas chromatography on the Perkin Elmer AutoSystem XL instrument. HP-1 (25 m x 0.20 $\mathrm{mm} \times 0.11 \mu \mathrm{m}$ ) capillary column was used for separation of compounds under the following experimental conditions: temperature program of column heating: $120{ }^{\circ} \mathrm{C}, 6{ }^{\circ} \mathrm{C} / \mathrm{min}, 300{ }^{\circ} \mathrm{C}(10 \mathrm{~min})$; carrier gas $\mathrm{H}_{2}(0.8$ $\mathrm{ml} / \mathrm{min})$; split injector $(1: 20)-160{ }^{\circ} \mathrm{C}, 8{ }^{\circ} \mathrm{C} / \mathrm{min}, 260$ ${ }^{\circ} \mathrm{C}$ (15 min); FID detector: $320^{\circ} \mathrm{C}$; injection volume 1 $\mu 1$. Betulinol (S2) served as standard in determination of phenolic compounds. The latter were calculated by comparison of the corresponding peak areas using correction factor 1.2. All results are expressed as milligram per gram of dry sample weight, where the limit of quantification was about $0.01 \mathrm{mg} / \mathrm{g}$ (Willfor, 2007).

\subsubsection{Characterization of phenolic compoudns by HPLC-SEC}

2.5.3. Karakterizacija fenolnih spojeva metodom HPLC-SEC

High performance size exclusion chromatography (HPLC-SEC) was used for the determination of molecular mass distribution of phenolic compounds. The presence of dimeric, trimeric and tetrameric phenols in representative ethanol extracts was thus confirmed as higher phenols can not be detected by gas chromatography due to their low volatility. The selected nonderivatized ethanol extracts of heartwood samples were dried under the stream of $\mathrm{N}_{2}$, after which they were redissolved in THF, so that the concentration was $1 \mathrm{mg} / \mathrm{ml}$. The analyses were carried out on the chromatographic system, composed of the following units: autosampler Spark Holland Marathon-XT, pump Shimadzu LC - 10ATVP, chromatographic columns 2x Jordi Gel DVB 500A (300 mm x $7.8 \mathrm{~mm}$ ) and detector Sedere SEDEX 85 ELSD, which is a low temperature evaporative light scattering detector. Tetrahydrofuran (THF) was used as eluent with the flow of $0.8 \mathrm{ml} / \mathrm{min}$. The injection volume was $50 \mu \mathrm{l}$.

\subsection{Gravimetric determination of the content of hydrophilic extractives}

2.6. Gravimetrijsko određivanje sadržaja hidrofilnih ekstraktiva

$10 \mathrm{ml}$ aliquots of ethanol extracts were dried under the stream of $\mathrm{N}_{2}$ and in vacuum desiccator at $40{ }^{\circ} \mathrm{C}$ until a constant weight was reached. The gravimetric amount of extractives was calculated as milligram per 
gram of dry sample weight. All quantitative determinations of hydrophilic extractives in the samples of heartwood were performed in two parallels. The presented results are average values of individual determinations.

\section{RESULTS AND DISCUSSION}

\section{REZULTATI I RASPRAVA}

\subsection{Gravimetric determination of ethanol extracts}

3.1. Gravimetrijsko određivanje etanolnih ekstrakata

Hexane extracted heartwood samples, from which lipophilics (free fatty and resin acids, diterpenoids, triglycerides, steryl esters and sterols) had been removed, were consecutively extracted in the same way by a polar solvent ethanol (95\%) to obtain hydrophilic extractives. Gravimetrically determined content of ethanol extract in the heartwood of both trees is presented in Figure 1. Evidently, the concentrations were slightly higher in the base of the trees $(0.5 \mathrm{~m})$, however they remained more or less constant further up the stems. The average values were $28.0 \pm 2.8 \mathrm{mg} / \mathrm{g}$ for Tree 1 and $30.5 \pm 2.7 \mathrm{mg} / \mathrm{g}$ for Tree 2, calculated on dry mass of heartwood. Obviously, there was no significant difference between the two trees.

Ethanol proved to be a suitable polar solvent. It is less toxic than methanol and less flammable than acetone. It can be easily recycled. The ASE extraction method has many advantages over commonly used Soxhlet method. It is automated and computer controlled. The whole process is very quick due to the application of elevated temperature and pressure, while solvent consumption is significantly reduced. It is indispensable method for sequential analyses of large numbers of samples. The results are comparable to Soxhlet.

\subsection{Identification of individual phenolic compounds (GC-MS)}

3.2. Identifikacija pojedinačnih fenolnih spojeva (GCMS)

Identification was performed by GC-MS analyses of two typical ethanol extracts of the heartwood of

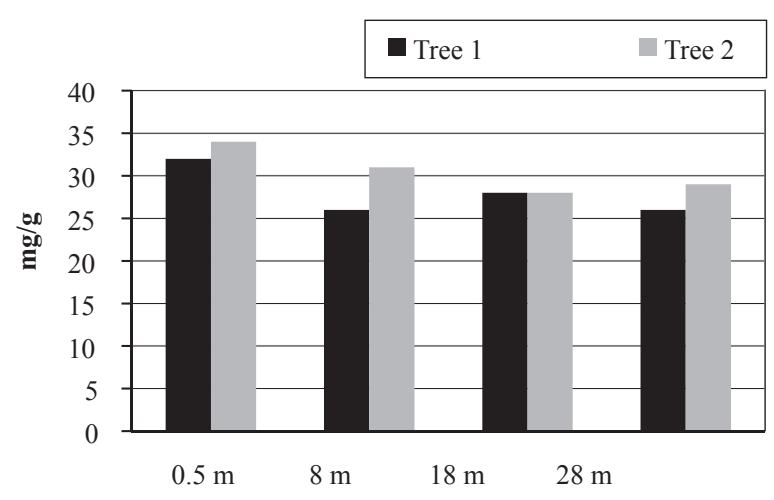

Figure 1 Content of ethanol extract in heartwood of trees 1 and 2 as a function of stem height

Slika 1. Sadržaj etanolnog ekstrakta srži stabla 1. i 2. na različitim visinama

tree 1 at 0.5 and $28 \mathrm{~m}$ of height. The following flavonoids and lignans were identified: naringenin, taxifolin (2 isomers), dihydrokaempferol, secoisolariciresinol, isoliovil, lariciresinol, todolactol A and nortrachelogenin. In addition, some monomeric and dimeric sugar units were also detected in the extracts.

\subsection{Determination of the composition of ethanol extracts related to stem height}

3.3. Određivanje sustava etanolnih ekstrakata u odnosu prema visini stabla

The composition of ethanol extracts was established from GC-FID chromatograms, recorded on a 25 $\mathrm{m}$ long capillary column. Qualitative composition of phenols was almost the same for all heartwood samples of both trees up to the stem height of $18 \mathrm{~m}$, while it considerably changed at the height of $28 \mathrm{~m}$ near the top of the trees. The flavonoids dihydrokaempferol and taxifolin predominated in all samples at lower and middle stem heights, where lignans were present only in trace amounts. On the other hand, the concentrations of lignans significantly increased at the top of both trees at $28 \mathrm{~m}$. Secoisolariciresinol was far the most abundant lignan in the heartwood of both trees.

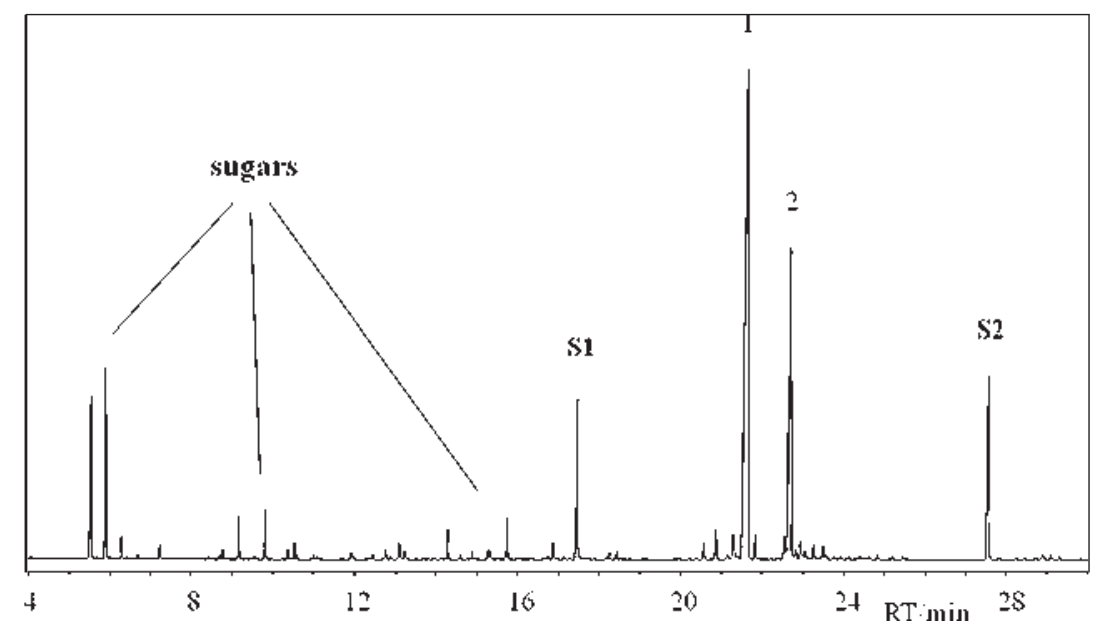

Figure 2 GC-FID chromatogram of ethanol extract of heartwood of tree $1(8 \mathrm{~m})$ (1 - dihydrokaempferol, 2 - taxifolin, S1, S2 - internal standards) Slika 2. GC-FID kromatogram etanolnog ekstrakta srži stabla 1. $(8 \mathrm{~m})$ (1 - dihidrokamferol, 2 - taksifolin, S1, S2 - interni standardi) 


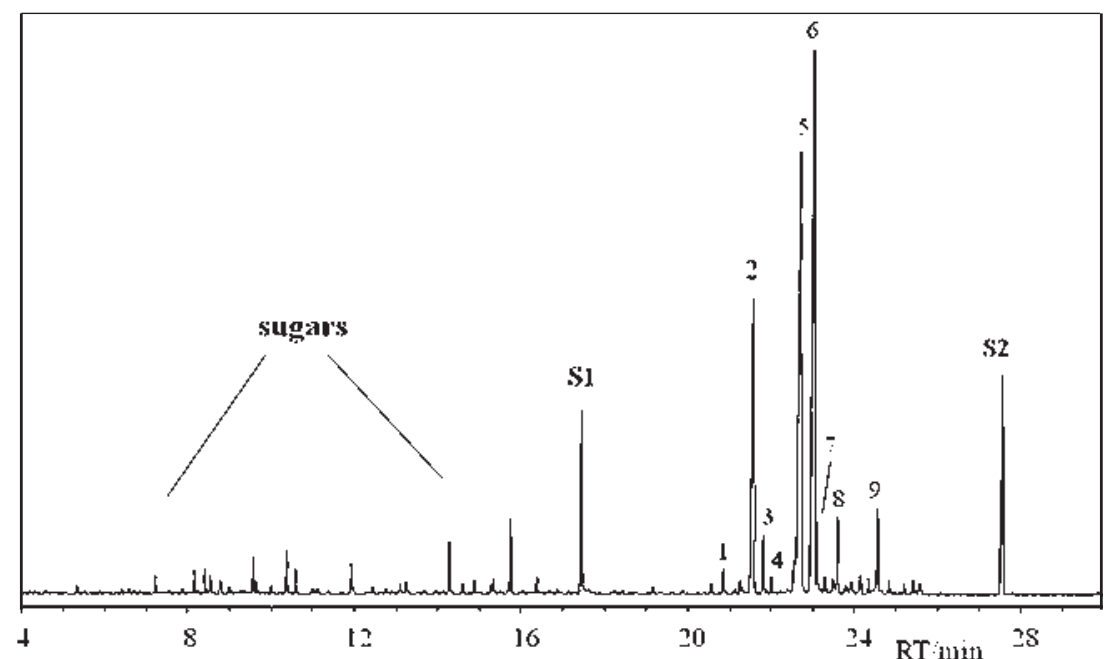

Figure 3 GC-FID chromatogram of ethanol extract of heartwood of tree 1 ( $28 \mathrm{~m})$

(1 - naringenin, 2 - dihydrokaempferol, 3 - taxifolin (isomer), 4 - todolactol A, 5 - taxifolin,

6 - secoisolariciresinol, 7 - isoliovil, 8 - nortrachelogenin, 9 - lariciresinol, S1, S2 - internal standards)

Slika 3. GC-FID kromatogram etanolnog ekstrakta srži stabla 1. $(28 \mathrm{~m})$

(1 - naringenin, 2 - dihidrokamferol, 3 - taksifolin (izomer), 4 - todolaktol A, 5 - taksifolin,

6 - sekoizolaricirezinol, 7 - izoliovil, 8 - nortrakelogenin, 9 - laricirezinol, S1, S2 - interni standardi)

GC-FID chromatograms of ethanol extracts of the heartwood of tree 1 at 8 and $28 \mathrm{~m}$ are presented in Figures 2 and 3.

Total flavonoid and lignan concentrations, which were calculated from the corresponding GC/FID chromatograms, varied between 10.6 and $12.6 \mathrm{mg} / \mathrm{g}$ in tree 1 , while the corresponding values in tree 2 were slightly higher - between 12.4 and $15.7 \mathrm{mg} / \mathrm{g}$. Concentrations of dihydrokaemferol were in the range between 1.8 and $7.1 \mathrm{mg} / \mathrm{g}$ and those of taxifolin between 3.3 and $8.4 \mathrm{mg} / \mathrm{g}$.

Secoisolariciresinol was the most abundant lignan and it was even the predominant phenolic compound at the top of tree 1 (Figure 4). The concentration of secoisolariciresionol in the heartwood of tree 1 at 28 $\mathrm{m}$ was $4.2 \mathrm{mg} / \mathrm{g}$ and in the heartwood of tree 2 at the

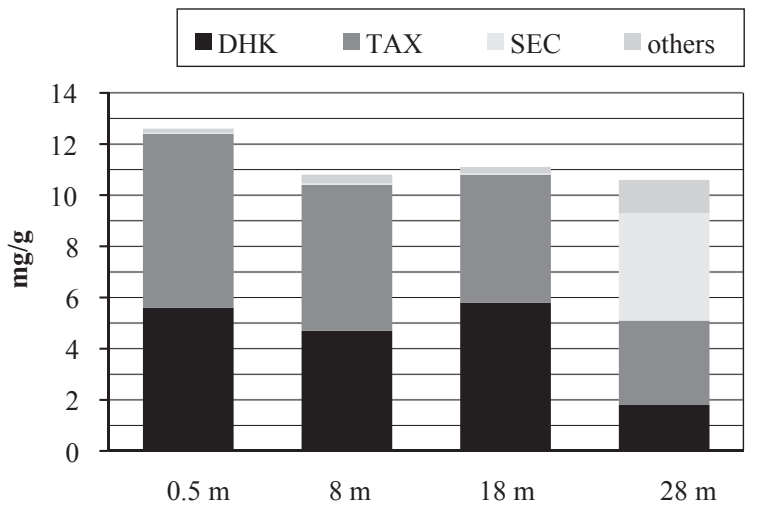

Figure 4 Content and composition of phenolic fraction of heartwood of tree 1 (DHK - dihydrokaempferol, TAX taxifolin, SEC - secoisolariciresinol, others - naringenin, taxifolin (is), todolactol A, isoliovil, nortrachelogenin, lariciresinol

Slika 4. Sadržaj i sustav fenolne frakcije srži stabla 1. (DHK - dihidrokamferol, TAX - taksifolin, SEC - sekoizolaricirezinol, ostalo - naringenin, taksifolin (iz.), todolaktol A, izoliovil, nortrakelogenin, laricirezinol) same height it was $3.4 \mathrm{mg} / \mathrm{g}$. It is very interesting that its concentration never exceeded $0.2 \mathrm{mg} / \mathrm{g}$ in the lower sections of heartwood.

The content and composition of phenols in the heartwood of trees 1 and 2 in relation to stem height is shown in Figures 4 and 5.

From the comparison of gravimetric and chromatographic results, it was evident that the contents of ethanol extracts were at least twice as high as the chromatographically determined concentrations of flavonoids and lignans in those extracts. This could be partly ascribed to the presence of different sugar units, such as mono- and disaccharides in ethanol extracts, as they are readily soluble in polar solvents. However, some substances, which were simultaneously extracted by ethanol, could not be detected by GC-FID due to their

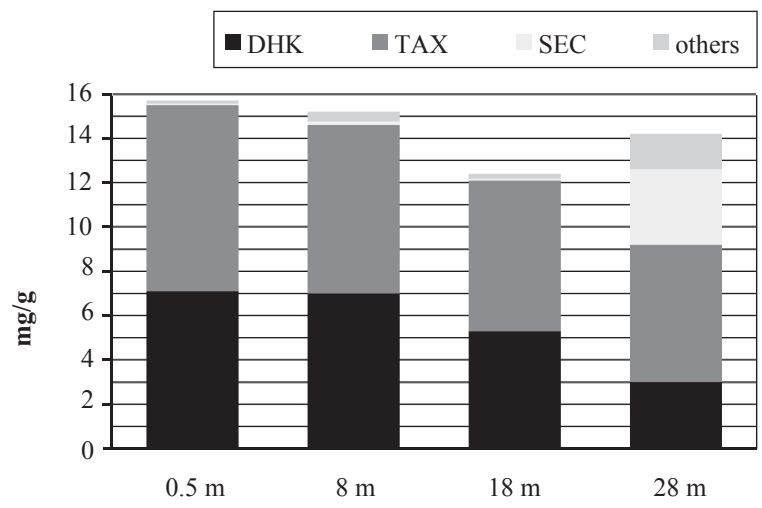

Figure 5 Content and composition of phenolic fraction of heartwood of tree 2 (DHK - dihydrokaempferol, TAX taxifolin, SEC - secoisolariciresinol, others - naringenin, taxifolin (is), todolactol A, isoliovil, nortrachelogenin, lariciresinol)

Slika 5. Sadržaj i sustav fenolne frakcije srži stabla 2. (DHK - dihidrokamferol, TAX - taksifolin, SEC - sekoizolariciresinol, ostalo - naringenin, taksifolin (iz.), todolaktol A, izoliovil, nortrakelogenin, laricirezinol) 


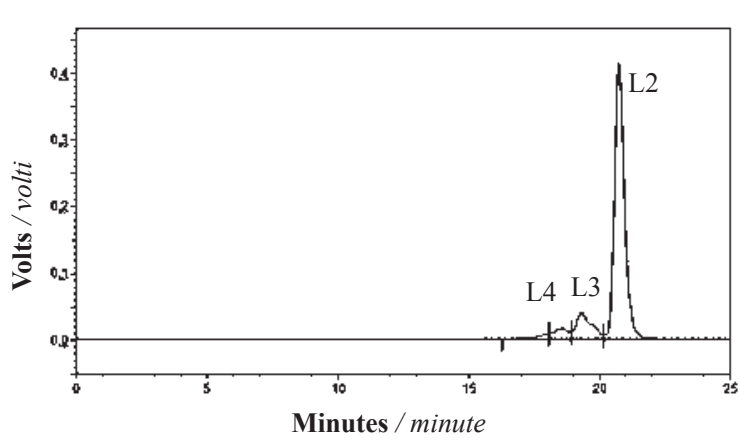

Figure 6 HPLC-SEC chromatogram of ethanol extract of heartwood of tree $1(8 \mathrm{~m})$

Slika 6. HPLC-SEC kromatogram etanolnog ekstrakta srži stabla 1. $(8 \mathrm{~m})$

higher molecular mass and thus lower volatility. The presence of higher phenolic structures was unambiguously confirmed by HPLC-SEC (Figure 6).

Figure 6 shows the molecular mass distribution of a THF redissolved typical ethanol extract. The most intensive peak (L2) with the retention time of $21 \mathrm{~min}$ represents dimeric phenols, e.g. flavonoids and lignans, while weaker peaks with retention times between 18 and $20 \mathrm{~min}$ (L3 and L4) simbolize higher phenols having three and four phenolic groups in their molecular structure. According to the peak area ratio, it could be estimated that typical ethanol extracts of larch heartwood contained averagely about $20 \%$ of higher phenols. Sugar units and other non phenolic components were not detected by HPLC-SEC under specified experimental conditions.

The most abundant phenolic compounds of European larch, e.g. dihydrokaempferol, taxifolin and secoisolariciresinol exhibit, according to available literature data, very strong antioxidative properties, which can be ascribed to their specific molecular structure. The structural formulas of the most typical larch flavonoids and lignans are presented in Figure 7.<smiles>O=C1c2c(O)cc(O)cc2O[C@@H](c2ccc(O)c(O)c2)C1O</smiles>

(1)<smiles>COc1cc(C[C@@H](CO)[C@H](CO)Cc2ccc(O)c(OC)c2)ccc1O</smiles>

The biological activity of taxifolin could be attributed to the relatively high content of phenolic hydroxyl groups in the right ring of its molecular structure, while on the other hand secoisolariciresinol is very efficient antioxidant on account of its butanediol structure (Figure 7). Presence of higher trimeric and tetrameric phenols also positively affects antioxidative properties of extractives and thus biological resistance of wood tissues against rotting (Pietarinen et al. 2006; Willför et al. 2003; Scalbert, 1991; De Bruyne et al. 1999).

The most significant finding in the case of larch heartwood was that chemical structure of hydrophilic extractive fraction changed towards the top of both examined trees, which was not the case with lipophilic fraction of the same tissues (Zule et al., 2015). While the flavonoids taxifolin and dihydrokaempferol predominated in the majority of heartwood, lignans appeared at the top in abundant concentrations with secoisolariciresinol as the main phenolic compound. Such distribution points to the fact that lignans are synthesized during early growth period, while later on, during wood aging, the synthesis proceeds more and more in the direction of flavonoid formation (Willför, 2002).

Larch forest residues, such as tree tops, damaged wood, cuttings, sawdust, knots and branches from wood processing could serve as relevant source for large scale isolation of valuable bioactive compounds. The latter may be applied as "green chemicals" or natural preservatives in farmaceutic, food, chemical and other industries. The remaining extracted wood may be further chemically converted to different platform chemicals and biofuel, which is the main idea of wood biorefineries.

\section{CONCLUSIONS \\ 4. ZAKLJUČCI}

Nine different phenolic compounds, such as flavonoids and lignans were determined in ethanol ex-<smiles>O=C1c2c(O)cc(O)cc2O[C@H](c2ccc(O)cc2)C1O</smiles>

(2)

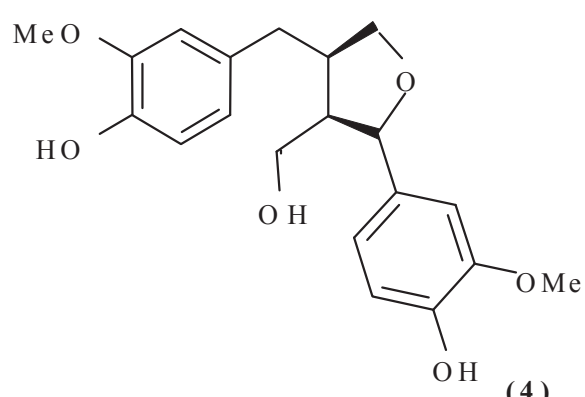

Figure 7 Structural formulas of taxifolin (1), dihydrokaempferol (2), secoisolariciresinol (3) and lariciresinol (4) Slika 7. Strukturne formule taksifolina (1), dihidrokemferola (2), sekoizolaricirezinola (3) i laricirezinola (4) 
tracts of the heartwood of two European larch trees. All substances identified, e.g. naringenin, taxifolin (2 isomers), dihydrokaempferol, secoisolariciresinol, lariciresinol, isoliovil, northrachelogenin and todolactol A, are typical for larch species (European, Siberian, Japanese, Western, Tamarack and others) and are commonly not found in other conifers in any significant amounts. Their average concentrations in the heartwood of the two examined trees were $12 \pm 2 \mathrm{mg} / \mathrm{g}$ and $15 \pm 2 \mathrm{mg} / \mathrm{g}$, and did not change essentially in vertical direction along the stems. Flavonoids predominated at lower and middle positions while lignans were more abundant at the top of both trees. The most important flavonoid taxifolin and lignan secoisolariciresinol are classified as very powerful antioxidants which, in combination with other phenolic substances, most likely provides efficient chemical protection of larch heartwood against rotting and harsh environmental conditions. Our study may contribute to better understanding of the chemistry of wood tissues.

\section{Acknowlegement - Zahvala}

Analyses were performed at the Åbo Akademi University, Turku, Finland. Authors are gratefully thankful to prof. Bjarne Holmbom and the members of his staff - Jarl Hemming, Andrey Pranovich and Markku Reunanen for substantial help and cooperation.

\section{REFERENCES}

5. LITERATURA

1. Aleksandrova, N. B.; Kuznetsova, S. A.; Kuznetsov, B. N.; Danilov, V. G.; Tarabank,V. E.; Shambazov, V. K., 2002: Integrated processing of larch wood biomass to fine chemicals. V: $7^{\text {th }}$ European Workshop on Lignocellulosics and Pulp, Turku: 495-498.

2. Babkin, V. A.; Ostroukhova, L. A., 1999: Larch bark as a source of biologically active products. V: $10^{\text {th }}$ ISWPC International Symposium on Wood and Pulping Chemistry, Yokohama, June 7-10: 484-485.

3. Babkin, V. A.; Ostroukhova, L. A.; Malkov Yu, A.; Babkin, D. V.; Onuchina, N. A.; Ivanova, S. Z., 2001: Isolation of biologically active compounds from larch wood.V: $11^{\text {th }}$ ISWPC nternational Symposium on Wood and Pulping Chemistry, Nice, June 11-14: 119-122.

4. Bohm, B. A., 1998: Introduction to flavonoids. Singapore: Harwood Academic Publishers, p. 592.

5. Brewerton, H. V., 1956: Extractives of Larix decidua and Larix leptolepis. New Zeland Journal of Science and Technology, 37B: 626-632.

6. De Bruyne, T.; Pieters, L.; Deelstra, H.; Vlietinck, A., 1999: Condensed vegetable tannins: biodiversity in structure and biological activities. Biochemical Systematics and Ecology, 27: 445-459. http://dx.doi.org/10.1016/S0305-1978(98)00101-X.

7. Celimene, C.; Micales, J.; Ferge, L.; Young, R.,1999: Efficacy of pinosylvins against white rot and brown rot fungi. Holzforschung, 53 (5): 491-497. http://dx.doi.org/10.1515/HF.1999.081.

8. Chui, Y. H.; MacKinnon-Peters, G., 1995: Wood properties of exotic larch grown in eastern Canada and northeastern United States. The Forestry Cronicle, 71 (5): 639646. http://dx.doi.org/10.5558/tfc71639-5.

9. Debell, J. D.; Morell, J. J.; Gartner, B., 1997: Tropolone content of increment cores as an indicator of decay resist- ance in western red cedar. Wood and Fiber Science, 29: 364-369.

10. Doi, S.; Kurimoto, Y.; Ohmura, Y.; Aoyama, M.; Ohara, S., 1998: Attractive factors of steam- treated larch wood to termite feeding. V: $29^{\text {th }}$ Annual Meeting of the IRG, Maastricht, Netherlands, 14-19 June: 1-9.

11. Eaton, R. A.; Hale, M. D. C., 1993. Wood: Decay, pests and protection. Vol 1. London, Chapman \& Hall, p. 455.

12. Gardner, J. A. F.; Barton, G. M., 1960: The distribution of dihydroquercetin in Douglas-fir and western larch. Forest Products Journal, 10 (3): 171-173.

13. Gierlinger, N.; Jacques, D.; Marchal, M.; Wimmer, R.; Schwanninger, M.; Paques, L. E., 2002: Heartwood extractives and natural durability of larch - relationships and their prediction by FT-NIR spectroscopy. V: Proceedings of improvement of larch (Larix $s p$.) for better growth, stem form and wood quality, Gap - Auvergne \& Limousin. INRA, Olivet Cedex, 414-421.

14. Gierlinger, N.; Schwanninger, M.; Wimmer, R.; Hinterstoissser, B.; Jacques, D.; Paques, L. E., 2003: Estimation of extractives, lignin and natural durability of larch heartwood (Larix spp.) by FT-NIR spectroscopy. V: $12^{\text {th }}$ Internation Symposium on Wood and Pulping Chemistry, Madison, USA, vol III: 51-54.

15. Gierlinger, N.; Jacques, D.; Schwanninger, M.; Wimmer, R.; Paques, L. E., 2004: Heartwood extractives and lignin content of different larch species (Larix sp.) and relationships to brown-rot decay resistance. Trees, 18: 230-236. http://dx.doi.org/1007/s00468-003-0300-0.

16. Giwa, S. A. O.; Swan, E. P., 1975: Heartwood extractives of a western larch tree (Larix occidentalis Nutt.). Wood and Fiber, 7 (3): 216-221.

17. Gripenberg, J., 1952: Flavanones from the heartwood of Larix decidua Mill. Acta Chemica Scandinavica, 6: 1152-1156.

https://doi.org/10.3891/acta.chem.scand.06-1152

18. Hart, J., 1989: Role of wood exudates and extractives in protecting wood from decay. V: Natural products of woody plants II. Berlin, Springer, p. 1120. http://dx.doi.org/10.1007/978-3-642-742-740-75-6_22.

19. Hillis, W. E., 1962: Wood Extractives and their significance to the pulp and paper industries. New York, Academic Press, p. 572.

20. Ivanova, S. Z.; Gorshkov, A. G.; Kuzmin, A. V.; Gordienko, I. I.; Babkin, V. A., 2012: Phenolic compounds of Siberian and Dahurian larch phloem. Russian Journal of Bioorganic Chemistry 38: 769-774. http://dx.doi.org/10.1134/S1068162012070096.

21. Keith, C. T.; Chauret, G., 1988: Basic wood properties of European larch from fast-growth plantations in eastern Canada. Canadian Journal of Forest Research, 18: 13251331. http://dx.doi.org/1325-1331, 10.1139/x88-204.

22. Kleist, G.; Schmitt, U., 1999: Evidence of accessory compounds in vessel walls of Sapelli heartwood (Entandrophragma cylindricum) obtained by transmission electron microscopy. Holz als Roh-und Werkstoff, 57: 93-95. http://dx.doi.org/10.1007/PL00002633.

23. Kolhir, V. K.; Bykov, V. A.; Baginskaja, A. I.; Sokolov, S. Y.; Glazova, N. G.; Leskova, T. E.; Sakovich, G. S.; Tjukavkina, N. A.; Kolesnik, Y. A.; Rulenko, I. A., 1996: Antioxidant activity of a dihydroquercetin isolated from Larix gmelinii (Rupr.) Rupr. wood. Phytotherapy research, 10: 478-482.

24. Lapteva, K. I.; Tyukavkina, Ya.; Ryzhova, L. I., 1971: Lignans from Larix dahurica and Larix sibirica wood. Khim. Prir. Soedin, 7 (6): 829-830. http://dx.doi.org/10.1007/BF00567947. 
25. Nair, G. V.; von Rudloff, E., 1960: Chemical composition of the heartwood extractives of Larix lyallii. Canadian Journal of Chemistry, 38: 177-181. https://doi.org/10.1139/v60-023.

26. Ostroukhova, L. A.; Raldugin, V. A.; Babkin, V. A.; Onuchina, N. A.; Levchuk, A. A., 2012: Investigation of the chemical composition of larch wood resin. Russian Journal of Bioorganic Chemistry, 38: 775-779. http://dx.doi.org/10.1134/S1068162012070151.

27. Ohmura, W.; Doi, S.; Aoyama, M.; Ohara, S., 1999: Components of steamed and non-steamed Japanese larch (Larix leptolepis (Sieb. et Zucc.) Gord) heartwood affecting the feeding behavior of the subterranean termite, Coptotermes formosanus shiraki (Isoptera: Rhinotermitidae). Holzforschung, 53 (6): 569-574.

http://dx.doi.org/10.1515/HF.1999.094.

28. Pietarinen, S. P.; Willför, S. M.; Ahotupa, M. O.; Hemming, J. E.; Holmbom, B. R., 2006: Knotwood and bark extracts: strong antioxidants from waste materials. Journal of Wood Science, 52: 436-444. http://dx.doi.org/10.1007/s10086-005-0780-1.

29. Rennerfelt, E.; Nacht, G., 1955: The fungicidal activity of some constituents from heartwood of conifers. Svensk. Bot. Tidskr., 49: 419-432.

30. Sasaya, T.; Demachi, S.; Terazawa, M., 1970: Studies on the extractives of larch. Report 2. Determination of flavonoids in Larix leptolepis. Research Bulletins of the Experiment Forest Hokkaido University, 27 (2): 429-443.

31. Scalbert, A., 1991: Antimicrobial properties of tannins. Phytochemistry, 30: 3875-3883.

32. Sjöstrom, E., 1981: Wood chemistry-fundamentals and applications. New York, Academic Press: p. 223.

33. Stenius, P. (ed.), 2000: Forest Products Chemistry. Book 3 (Papermaking Science and Technology). Fapet Oy, Jyväskylä, Finland, p. 350.

34. Tyukavkina, N. A.; Lapteva, K. I.; Medvedeva, S. A., 1973: Phenolic extractives of the genus Larix. A review. Khimiya Drevesiny, 13: 3-17.

35. Wen-jie, W.; Xue-ying, L.; Yuan-gang, Z., 2005: Dynamic feature of flavonoids content in different organs of larch (Larix gmelinii). Journal of Forestry Research, 16: 89-92. http://dx.doi.org/10.1007/BF02857896.
36. Willför, S.; Hemming, J.; Reunanen, M.; Eckerman, C.; Holmbom, B., 2003: Lignans and lipophilic extractives in Norway spruce knots and stemwood. Holzforschung, 57 (1): 27-36. http://dx.doi.org/10.1515/HF.2003.005.

37. Willför, S.; Nisula, L.; Hemming, J.; Reunanen, M.; Holmbom, B., 2004. Bioactive phenolic substances in important tree species. Part 1. Knots and stemwood of spruce species. Holzforschung, 58 (4): 335-344. http://dx.doi.org/10.1515/HF.2004.052.

38. Willför, S. M.; Smeds, A. I.; Holmbom, B. R., 2006: Chromatographic analysis of lignans. Journal of Chromatography A., 1112: 64-77.

http://dx.doi.org/10.1016/j.chroma.2005.11.054.

39. Willför, S. M., 2007. Modern Analytical Tools for Pulp and Paper, Turku, 5-9 Nov., COSTE41 Course.

40. Willför, S., 2002: Water-soluble polysaccharides and phenolic compounds in Norway spruce and Scots pine stemwood and knots. Åbo Akademi University, Doctoral thesis.

41. Windeisen, E.; Wegener, G.; Lesnino, G.; Schumacher, P., 2002: Investigation of the correlation between extractives content and natural durability in 20 cultivated larch trees. Holz als Roh- und Werkstoff, 60: 373-374. http://dx.doi.org/10.1007/s00107-002-0314-0.

42. Windeisen, E.; Wegener, G., 2003: Chemical investigation of valuable cultivated larch trees. Holz als Roh-und Werkstoff, 61: 394-397. http://dx.doi.org/10.1007/s00107-003-0406-5.

43. Zule, J.; Čufar, K.; Tišler, V., 2015: Lipophilic Extractives in Heartwood of European Larch (Larix decidua Mill.). Drvna industrija, 66 (4): 305-313. http://dx.doi.org/10.5552/drind.2015.1442.

\section{Corresponding address:}

JANJA ZULE, Ph.D.

Pulp and Paper Institute

Bogišičeva 8

SI-1000 Ljubljana, Slovenia

e-mail: janja.zule@icp-lj.si 